\title{
Penerapan Model Harga Opsi Black-Scholes dalam Penetapan Premi Asuransi Jiwa Berjangka Unit Link
}

\author{
Felfin Ulfah Annisa ${ }^{1}$, Riaman ${ }^{2}$, , Betty Subartini $^{3}$ \\ ${ }^{1,2,3}$ Departemen Matematika FMIPA Universitas Padjadjaran \\ ${ }^{1}$ felfin_ua@yahoo.com, ${ }^{2}$ riaman@unpad.ac.id, ${ }^{3}$ subartinibetty@gmail.com
}

\begin{abstract}
Abstrak
Asuransi merupakan salah satu lembaga yang memiliki peran penting dalam kehidupan manusia karena disetiap waktu selalu ada resiko yang tidak bisa dihindari, termasuk kematian. Untuk mengantisipasi akibat setelah terjadinya resiko tersebut diperlukan suatu jaminan untuk biaya kehidupan selanjutnya, maka asuransi jiwa adalah pilihan yang tepat. Salah satunya adalah asuransi jiwa berjangka unit link yang merupakan produk asuransi yang menggabungkan fungsi proteksi dan fungsi investasi. Nilai manfaat yang diberikan oleh asuransi unit link bergantung pada nilai aset yang digunakan sebagai instrumen investasi. Dalam penelitian ini dibahas penerapan model Black-Scholes dalam penetapan premi asuransi jiwa berjangka unit link baik tanpa garansi maupun dengan garansi. Hasil simulasi numerik menunjukkan bahwa premi asuransi jiwa berjangka unit link dengan garansi lebih besar dibandingkan dengan premi asuransi jiwa berjangka unit link tanpa garansi, hal ini disebabkan oleh biaya yang diperlukan untuk memberikan garansi pada manfaat yang diperoleh pemegang polis.

Kata kunci: Asuransi Jiwa Berjangka, Unit Link, Premi Tunggal Bersih, Teorema Black-Scholes.
\end{abstract}

\begin{abstract}
Insurance is one of the institutions that have an important role in human life because at any time there is always an unavoidable risk, including death. To anticipate the consequences after the occurrence of such risk required a guarantee for the cost of subsequent life, then life insurance is the right choice. One of them is unit-linked term life insurance which is an insurance product that combines the functions of protection and the functions of investment. The value of benefits provided by unit-linked life insurance depends on the value of the asset used as an investment instrument. This research discuss about the application of Black-Scholes model in determination of unit linked term life insurance premiums without guarantee or with guarantee. Numerical simulation results show that premium unit link term life insurance with a greater guarantee compared to premium unit link term life insurance without warranty, this is due to the costs required to guarantee the benefits obtained by policyholders.

Keywords : Term Life Insurance, Unit Link, Net Single Premium, Black-Scholes Theorem
\end{abstract}

2000 Mathematics Subject Classification: 62P05 Received: 2018-07-30, accepted: 2018-10-30. 


\section{Pendahuluan}

Setiap individu manusia dalam kehidupannya setiap saat selalu dihadapkan pada resiko yang tidak bisa dihindari, seperti sakit, kecelakaan, kematian, dan sebagainya. Untuk mengantisipasi akibat setelah terjadinya resiko tersebut diperlukan suatu jaminan untuk biaya kehidupan selanjutnya. Salah satu bentuk penjaminan atau pengalihan risiko tersebut, asuransi jiwa adalah salah satu untuk mengantisipasi segala kemungkinan yang dapat terjadi tersebut. Tujuan polis asuransi jiwa dibeli bukan untuk mendekatkan diri dengan resiko kematian, tetapi untuk memastikan orang yang ditinggal tetap sejahtera. Asuransi jiwa adalah suatu kontrak perjanjian antara pemegang polis dengan perusahaan asuransi, di mana pihak asuransi berjanji untuk membayarkan nominal uang, apabila terjadi resiko kematian terhadap pihak pemegang asuransi/polis. Salah satu produk asuransi yang akan dicoba di sini adalah produk asuransi yang mengkombinasikan atara proteksi dan investasi. Premi asuransi ini dikenal sebagai produk unit link, yaitu polis asuransi jiwa individu yang memberikan manfaat proteksi asuransi jiwa dan juga kesempatan untuk berpartisipasi secara langsung dalam pengelolaan investasi yang setiap saat nilai polis bervariasi sesuai dengan nilai aset investasi tersebut. Peserta produk asuransi unit link ini, dapat memperoleh manfaat ganda, yaitu perlindungan asuransi dan investasi. Besarnya premi asuransi yang harus dibayar oleh pemegang polis tergantung pada penilaian risiko yang berkaitan dengan probabilitas kematian (tingkat kematian), tingkat pengembalian yang diharapkan, biaya yang diharapkan, dan jumlah klaim yang diharapkan, termasuk kematian dini atau pemegang polis masih hidup pada saat jatuh tempo kontrak asuransi. Penelitian ini fokus pada produk asuransi jiwa unit link. Produk unit link adalah salah satu produk asuransi jiwa yang muncul dalam beberapa tahun terakhir. Produk ini menyajikan masalah baru bagi aktuaris, karena beberapa masalah tidak dapat diselesaikan dengan pendekatan aktuaria tradisional. Permasalahannya menyangkut premi, seperti pada penelitian sebelumnya oleh Endang 2013 (lihat [1]) yang berjudul Premi tunggal bersih asuransi jiwa berjangka dengan faktor penebusan. Dalam penelitian tersebut hanya membahas bagaimana mencari premi tunggal bersih tetapi hanya berlaku untuk proteksi saja, sedangkan untuk investasi tidak ada. Oleh karena itu, dalam penelitian ini dibahas model premi asuransi jiwa untuk menentukan premi tunggal bersih yang diterapkan dari model harga opsi Black-Scholes. Pada prakteknya, instrumen yang digunakan dalam produk unit link adalah saham. Pembayaran premi dalam unit link merupakan penggabungan antara premi asuransi dengan pembayaran awal nilai investasi, sesuai dengan kontrak yang telah ditetapkan. Jenis asuransi yang digunakan dalam penelitian ini yaitu asuransi berjangka. Manfaat akan diterima oleh nasabah pada akhir tahun kematian nasabah, selama jangka waktu kontrak. Nasabah tidak akan mendapatkan manfaat apabila meninggal melebihi jangka waktu kontrak. Perusahaan asuransi memberikan manfaat dengan nilai yang berbeda sesuai nilai asset investasinya pada saat tersebut.

\section{Metode Penelitian}

Metodologi penelitian yang digunakan dalam penelitian ini adalah studi literatur dan simulasi numerik. Studi literatur yang dilakukan pada penelitian ini adalah mengkaji literatur yang berhubungan dengan masalah asuransi jiwa berjangka unit link. Penelitian sebelumnya yang menjadi bahan rujukan berjudul Design and Pricing of Equity-Linked Life Insurance Under Stochastic Interest Rates ( lihat Bacinello [2]). Penelitian ini terkait dengan penentuan model premi asuransi jiwa equity-linked dengan menggunakan model suku bunga stokastik. Penelitian lain yang juga dijadikan bahan rujukan yang dilakukan oleh Setiawan [3], dengan judul Permodelan Perhitungan Premi Asuransi Jiwa Dwiguna Unit Link dengan Garansi, serta berbagai referensi terkait penentuan model premi asuransi jiwa unit link. Simulasi numerik dilakukan untuk mengestimasi parameter model premi asuransi jiwa berjangka unit link ini, dengan penerapan model Black-Scholes.

2.1. Volatilitas Harga Saham. Langkah-langkah dalam menghitung nilai volatilitas harga saham adalah sebagai berikut (Hull [4]): 
(1) Menentukan return harga saham atau keuntungan harga saham dengan rumus:

$$
R_{t}=\ln \left(\frac{S_{t}}{S_{t-1}}\right)
$$

dengan $t$ adalah interval waktu pengamatan, $S_{t}$ sebagai harga saham pada waktu $t$, $S_{t-1}$ sebagai harga saham pada waktu $t-1$.

(2) Menentukan expected return harga saham atau tingkat keuntungan yang diharapkan dengan rumus:

$$
\bar{R}=\frac{\sum_{t=1}^{n} R_{t}}{n}
$$

dengan $n$ merupakan jumlah data return harga saham.

(3) Menentukan variansi dari return harga saham dengan rumus:

$$
s=\sum_{t=1}^{n} \frac{\left(R_{t}-\bar{R}_{t}\right)^{2}}{n-1}
$$

(4) Menentukan volatilitas yang dihitung dengan standar deviasi darireturn harga saham dengan rumus:

$$
\sigma=\frac{1}{\sqrt{\tau}} \sqrt{s}
$$

di mana $\tau=\frac{1}{T}$ dengan $T$ adalah jumlah hari perdagangan dalam 1 tahun, yaitu 252 hari.

2.2. Opsi Beli. price dan dalam jangka waktu tertentu yang disepakati, baik pada akhir masa jatuh tempo ataupun di antara tenggang waktu masa sebelum jatuh tempo.Opsi beli dinotasikan sebagai $C$. Keuntungan atau payoff yang diperoleh dari opsi beli adalah sebesar selisih antara harga saham waktu kontrak dengan strike price yang ditentukan $(S(T)-K)$. Rumusnya dapat dinyatakan sebagai berikut:

$$
C=\max ((S(T)-K, 0)
$$

2.3. Teorema Black Scholes. Jika terdapat variabel acak W yang berdistribusi lognormal dan variansi dari $\ln W$ adalah $v^{2}$, maka (Hull [4]):

$$
E[\max (W-K, 0)]=E[W] N\left(d_{1}\right)-K N\left(d_{2}\right)
$$

Misal pergerakan harga aset mengikuti Gerak Brown. Hal ini berarti bahwa $S_{t}$ berdistribusi lognormal atau $\ln S_{t}$ berdistribusi normal, maka:

$$
\begin{aligned}
& E\left(S_{t}\right)=e^{\ln S_{0}+\left(\mu-\sigma^{2} / 2\right) t+1 / 2 \sigma^{2} t} \\
& E\left(S_{t}\right)=S_{0} e^{\mu t}
\end{aligned}
$$

Harga saham diasumsikan mengikuti distribusi lognormal, yaitu

$$
\ln S_{t} \sim N\left[\ln S_{0}+\left(\mu-\frac{\sigma^{2}}{2}\right) t, \sigma^{2} t\right]
$$

2.4. Asuransi Jiwa Berjangka Unit Link. Asuransi jiwa adalah suatu kontrak perjanjian antara pemegang polis atau tertanggung dengan perusahaan asuransi sebagai penanggung. Perusahaan asuransi akan membayarkan sejumlah nominal uang jika terjadi risiko kematian terhadap pihak pemegang polis asuransi. Pembayaran premi dapat dilakukan dengan satu kali pembayaran di awal kontrak atau yang dikenal dengan premi tunggal. Sedangkan pembayaran manfaat kepada pihak tertanggung akan dilakukan pada akhir tahun kematian tertanggung selama masa kontrak masih berlaku.Variabel acak $X$ menyatakan usia pada saat pemegang polis meninggal dan $T=T(x)$ merupakan variabel acak yang menyatakan sisa usia pemegang polis terhitung sejak kontrak ditandatangani atau disebut future lifetime. Karena pembayaran manfaat dilakukan secara diskrit maka variabel acak yang dibutuhkan juga secara diskrit, 
yaitu $K(x)$ yang menyatakan lamanya tahun yang secara utuh dapat dilalui oleh pemegang polis berusia $x$ sebelum kematian yang disebut dengan curtate-future lifetime. Nilai dari $K(x)$ merupakan bilangan bulat terbesar yang lebih kecil atau sama dengan $T(x)$. Oleh karena itu, fungsi densitas probabilitas $\mathrm{K}$ adalah fungsi dari $T$, yaitu:

$$
\begin{aligned}
\operatorname{Pr}[K(x)=k] & =\operatorname{Pr}[k<T(x) \leq k+1] \\
& =\operatorname{Pr}[T(x) \leq k+1]-\operatorname{Pr}[T(x) \leq k] \\
& =\frac{l_{x}-l_{x+k+1}}{l_{x}}-\frac{l_{x}-l_{x+k}}{l_{x}} \\
& ={ }_{k} p_{x} \cdot q_{x+k}
\end{aligned}
$$

Untuk $k=0,1,2$, di mana $k$ merupakan tahun curtate-future lifetime dari pemegang polis ${ }_{k} p_{x}$ merupakan peluang hidup orang berusia $x$ paling sedikit selama $k$ tahun dan $q_{x+k}$ merupakan peluang orang berusia $(x+k)$ tahun meninggal dalam kurun waktu 1 tahun. Dalam menghitung besar premi terdapat tiga fungsi yang akan digunakan, di antaranya adalah:

(1) Fungsi manfaat : suatu fungsi dari pemberian manfaat oleh pihak asuransi yang diasumsikan sebesar 1 bila diberikan dan 0 bila tidak diberikan. Fungsi dari manfaat yang diperoleh pada saat $(k+1)$ dinotasikan $b_{k+1}$.

$$
b_{k+1}=1, k=0,12, n-1
$$

(2) Fungsi diskon : faktor diskon dari waktu pembayaran yang dihitung mundur ke waktu polis diterbitkan. Fungsi diskon digunakan untuk menghitung nilai tunai dari manfaat yang akan diberikan pemegang polis yang dinotasikan dengan $v_{k+1}$. Fungsi diskon adalah fungsi suku bunga untuk menjumlahkan pendapatan di masa mendatang bila dinilai dalam waktu sekarang.

$$
\begin{aligned}
v_{k+1} & =v^{k+1}, k=0,12,, n \\
& =e^{-\delta(k+1)} \\
& \delta=\ln (1+r)
\end{aligned}
$$

(3) Fungsi nilai tunai : fungsi yang menyatakan nilai sekarang dari manfaat yang akan diberikan kepada pemegang polis saat klaim terjadi, dinotasikan dengan $z_{k+1}$. Variabel acak yang menyatakan nilai tunai dari manfaat adalah $Z$.

$$
Z=v^{k+1}, k=0,12, n-1
$$

Premi tunggal bersih dalam pembayaran asuransi adalah nilai harapan dari variabel random $Z$ atau biasa disebut Actuarial Present Value (APV) atau nilai tunai aktuaria (Bowers [5]).

$$
A_{x \bar{n}}^{1}=E[Z]=\sum_{k=0}^{n-1} v^{k+1}{ }_{k} p_{x} \cdot q_{x+k}
$$

${ }_{k} p_{x} . q_{x+k}$ menyatakan peluang bersyarat seseorang yang berusia $x$ tahun akan meninggal antara usia $x+k$ sampai dengan $x+k+1$ Asuransi unit link mengelola dan menginvestasikan sebagian dari premi yang dibayarkan oleh nasabah. Unit link dapat dikatakan sebagai kontrak yang menggabungkan nilai manfaat dengan aset keuangan. Nilai manfaat yang diperoleh pemegang polis asuransi unit link tidak tetap karena bergantung dengan harga aset.

2.5. Asuransi Jiwa Berjangka Unit Link Tanpa Garansi. Harga aset diasumsikan mengikuti Gerak Brown Geometris dengan laju konstan sebesar $\delta$, maka:

$$
E\left[S_{k}\right]=S_{0} e^{\delta k}
$$

$S_{k}$ menyatakan satuan harga dari sebuah portfolio yang dibayar saat $k$ dan $S_{0}$ merupakan satuan harga dari sebuah portfolio yang dibayar pada awal investasi dilakukan. Fungsi nilai tunainya dapat dituliskan:

$$
Z_{k+1}=e^{-\delta(k+1)} \cdot S_{k}, k=0,1,2,, n-1
$$


Premi tunggal bersih asuransi jiwa berjangka unit link tanpa garansi:

$$
A_{x . \bar{n}}^{1}=e^{-\delta} \sum_{k=0}^{n-1}{ }_{k} p_{x} q x+k . S_{0}
$$

2.6. Asuransi Jiwa Berjangka Unit Link dengan Garansi. Asuransi jiwa Unit Link dengan garansi memberikan manfaat kepada pemegang polis sebesar nilai dari investasi pada saat klaim terjadi atau minimal sebesar garansi yang telah disepakati pada saat kontrak awal (Bacinello [2]). Asumsikan bahwa besar garansi pada saat $k$ yang dinotasikan dengan $G_{k}$ dirumuskan dengan

$$
G_{k}=S_{0} e^{\delta k}
$$

Persamaan (18) dapat dipandang sebagai payoff dari opsi call Eropa dengan $G_{k}$ sebagai strike price. Oleh karena itu, dengan menggunakan valuasi risk-neutral dapat ditentukan harga opsi yang dalam hal ini merupakan harga manfaat pada saat waktu 0 (lihat $[6]$ ).

$$
\begin{aligned}
U(k+1) & =E\left[v_{k+1} \max \left[S_{k}, G_{k}\right]\right] \\
& =e^{-\delta}\left\{e^{-\delta k} G_{k}+e^{-\delta k} \cdot E\left[\max \left[S_{k}-G_{k}, 0\right]\right]\right\}
\end{aligned}
$$

digunakan teorema Black-Scholespada persamaan (6)untuk opsi call Eropa, maka:

$$
\begin{aligned}
U(k+1) & =E\left[v_{k+1} \max \left[S_{k}, G_{k}\right]\right] \\
& =e^{-\delta}\left\{e^{-\delta k} G_{k}+e^{-\delta k} \cdot E\left[\max \left[S_{k}-G_{k}, 0\right]\right]\right\} \\
U(k) & =S_{0}+S_{0} N\left(d_{1}\right)-G_{k} e^{-\delta k} N\left(d_{2}\right)
\end{aligned}
$$

dengan

$$
d_{1}=\frac{\ln \left(\frac{S_{0}}{G_{k}}\right)+\left(r+\frac{\sigma^{2}}{2}\right) k}{\sigma \sqrt{k}} \operatorname{dand}_{2}=d_{1}-\sigma \sqrt{k}
$$

Premi tunggal bersih asuransi jiwa berjangka unit link dengan garansi adalah

$$
A_{x \bar{n}}^{1}=e^{-\delta} \sum_{k=0}^{n-1} \cdot k p_{x} \cdot q_{x+k} \cdot U(k)
$$

\section{Hasil DAN Pembahasan}

3.1. Data Harga Penutupan Saham AALI. Data harga penutupan saham AALI selama 1 tahun periode 27 Desember 2016 s.d 27 Desember 2017 secara berurutan.

Tabel 1. Data harga penutupan saham

\begin{tabular}{||cc||}
\hline Date & Close \\
\hline \hline Dec 27,2016 & 17000 \\
\hline Dec 28,2016 & 17125 \\
\hline Dec 29,2016 & 17250 \\
\hline$\vdots$ & $\vdots$ \\
\hline Dec 27,2017 & 13225 \\
\hline
\end{tabular}

\subsection{Asumsi-Asumsi.}

(1) Bunga yang digunakan adalah konstan, yaitu sebesar 0,065 atau 6,5\%

(2) Pembelian saham adalah 1000 lembar dan nilai awal saham yang digunakan sebesar Rp 17.000,00

(3) Pihak tertanggung merupakan laki-laki yang berusia 40 tahun.

(4) Jangka waktu asuransi adalah 10 tahun, 15 tahun, 20 tahun, 25 tahun dan 30 tahun.

(5) Tabel Mortalita yang digunakan merupakan Tabel Mortalita Indonesia 2011.

(6) Garansi diasumsikan mengikuti fungsi seperti pada persamaan (17)

(7) Harga saham diasumsikan mengikuti distribusi lognormal.

(8) Tidak ada biaya yang diperhitungkan 


\subsection{Menghitung Volatilitas Harga Saham.}

(1) Hasil perhitungan return harga saham dapat dilihat pada Tabel 2 di bawah ini.

Tabel 2. Hasil perhitungan returnharga penutupan saham

\begin{tabular}{||ccc||}
\hline $\mathrm{t}$ & Close & $R_{t}$ \\
\hline 0 & 17000 & - \\
\hline 1 & 17125 & 0,00733 \\
\hline 2 & 17250 & 0,00727 \\
\hline$\vdots$ & $\vdots$ & $\vdots$ \\
\hline 255 & 13225 & 0,02101 \\
\hline
\end{tabular}

(2) Menghitung expected return harga saham.

$$
\bar{R}=\frac{-0,2511}{255}=-0,00098
$$

(3) Menghitung variansi dari return harga penutupan saham. Hasil Perhitungan Nilai $\left(R_{t}-\bar{R}_{t}\right)^{2}$ dapat dilihat pada Tabel 2.3.

Tabel 2.3. Hasil perhitungan nilai $\left(R_{t}-\bar{R}_{t}\right)^{2}$

\begin{tabular}{||ccccc||}
\hline $\mathrm{t}$ & Close & $R_{t}$ & $R_{t}-\bar{R}_{t}$ & $\left(R_{t}-\bar{R}_{t}\right)^{2}$ \\
\hline 0 & 17000 & - & - & - \\
\hline 1 & 17125 & 0,00733 & 0,00831 & 0,00007 \\
\hline 2 & 17250 & 0,00727 & 0,00825 & 0,00007 \\
\hline$\vdots$ & $\vdots$ & $\vdots$ & $\vdots$ & $\vdots$ \\
\hline 255 & 13225 & 0,02101 & 0,02199 & 0,00048 \\
\hline \multicolumn{5}{c}{0,03496} \\
& $s=\frac{0,00014}{254}=0,000$
\end{tabular}

(4) Menghitung volatilitas harga saham.

$$
\sigma=\sqrt{(252)(0,00014)}=0,18782
$$

Sehingga diperoleh volatilitas saham sebesar 0,18782 atau 18,78\%

3.4. Premi Tunggal Bersih Asuransi Jiwa Unit Link Tanpa Garansi. Dengan harga saham awal $\left(S_{0}\right)$ yang digunakan adalah sebesar Rp 17.000,00 dan bunga sebesar 6.5\%, maka force of interest dapat dihitung menggunakan rumus persamaan (12):

$$
\delta=\ln (1+0.065)=0.06297
$$

Premi tunggal bersih asuransi jiwa berjangka 30 tahun unit link tanpa garansi dengan rumus persamaan (17):

$$
\begin{aligned}
A_{4} 0: \overline{30}^{1} & =e^{-0.06297} \cdot\left({ }_{0} p_{4} 0 . q_{4} 0+{ }_{1} p_{4} 0 . q_{4} 1+{ }_{2} p_{4} 0 . q_{4} 2+\cdots+{ }_{29} p_{4} 0 . q_{6} 9\right)(17000) \\
& =0,938967136(0,00153+0,0017473+0,0019536+\ldots+0,021609)(17000) \text { Premi } \\
& =4498,6668
\end{aligned}
$$

tunggal bersih asuransi jiwa berjangka 30 tahun unit link tanpa garansi dengan harga saham awal $\left(S_{0}\right)$ adalah Rp 17.000,00 dan jumlah lembar sahamnya adalah 1000 lembar yaitu Rp 4.498.666,83.

Tabel 4. Premi asuransi jiwa berjangka tanpa garansi untuk beberapa jangka waktu

\begin{tabular}{lll}
\hline Umur & Jangka Waktu & Premi bersih tunggal \\
\hline 40 Tahun & 10 Tahun & Rp $446.729,23$ \\
& 15 Tahun & Rp $983.489,56$ \\
& 20 Tahun & Rp $1.819 .247,39$ \\
& 25 Tahun & Rp $2.951 .735,39$ \\
& 30 Tahun & Rp $4.498 .666,83$ \\
\hline
\end{tabular}


3.5. Premi Tunggal Bersih Asuransi Jiwa Unit Link dengan Garansi. Garansi dapat dihitung menggunakan persamaan (18), yaitu:

$$
G_{k}=17000 \cdot e^{0,06297(k)}
$$

Premi tunggal bersih asuransi jiwa berjangka 30 tahun unit link dengan garansi dengan rumus persamaan (23):

$$
\begin{aligned}
A_{40: 30}^{1} & \left.=e^{-0.06297} \cdot\left({ }_{0} p_{40} \cdot q_{40}\right)(17000)+\left({ }_{1} p_{4} 0 . q_{4} 1\right)(18271,6)+\cdots+{ }_{29} p_{40} \cdot q_{69}\right)(23567,1) \\
& =0,938967136(0,00153)(17000)+(0,0017473)(18271,6)+\cdots+(0,021609)(23567,1) \\
& =5927,02318
\end{aligned}
$$

Premi tunggal bersih asuransi jiwa berjangka 30 tahun unit link dengan garansi dengan harga saham awal $\left(S_{0}\right)$ adalah Rp 17.000,00 dan jumlah lembar sahamnya adalah 1000 lembar, yaitu Rp 5.927.023,18.

Tabel 5 Premi asuransi jiwa berjangka dengan garansi untuk beberapa jangka waktu

\section{Kesimpulan}

Kesimpulan yang dapat diambil dari penelitian ini adalah nilai tunai manfaat atau nilai premi tunggal bersih asuransi jiwa berjangka unit link dengan garansi, digunakan model harga opsi beli Black Scholes yang terdapat pada persamaan (21).Hasil simulasi dari penetapan premi asuransi jiwa berjangka unit link tanpa dan dengan garansi untuk 1000 lembar saham dapat disimpulkan bahwa premi asuransi jiwa berjangka unit link dengan garansi lebih besar daripada premi asuransi jiwa berjangka unit link tanpa garansi dan semakin lama jangka tahun maka premi yang dibayarkan juga akan semakin besar.

\section{DAFTAR Pustaka}

[1] Endang, Sri Kresnawati (2013), Premi Tunggal Bersih Asuransi Jiwa Berjangka dengan factor Penebusan, Universitas Negeri Yogyakarta, Yogyakarta.

[2] Bacinello, A.R., Design and Pricing of Equity-Linked Life Insurance Under Stochastic Interest Rates. Journal of Risk Finance, 1995.

[3] Setiawan, Bernika, Permodelan perhitungan premi asuransi jiwa dwiguna unit link dengan garansi. Universitas Parahyangan, Bandung, (2016)

[4] Hull, J.C.,Options, Futures, And Other Derivatives, 8th Edition. Pearson Education, Inc, Edinburgh Gate, England, 2012.

[5] Bowers, N.L., Actuarial Mathematics, 2nd Edition. The Society of Actuaries, United States of America, 1997.

[6] Brennan, M.J. and Schwartz, E.S., The Pricing of Equity-Linked Life Insurance Policies with an Asset Value Guaranteed. Journal of Financial Economics, 3, Pages 195-213, (1976). 
